\title{
Mercury isotopic composition of the \\ Eocene Arctic Ocean: No evidence for volcanic loading signal at the PETM?
}

\section{JAMES D. GLEASON}

University of Michigan

Presenting Author: jdgleaso@umich.edu

A review of mercury abundances and isotopic compositions in Arctic Ocean marine sediments [1], including the 56 Ma PETM, is placed in the context of recent studies. The Cenozoic Arctic Ocean dataset, representing a variety of depositional environments, water depths and stratigraphic ages, is summarized here. Total range of mass dependent fractionation (MDF) and odd-mass independent fractionation (odd-MIF) of $\mathrm{Hg}$ stable isotopes was: $\delta^{202} \mathrm{Hg}(\mathrm{MDF})=-2.34 \%$ o to $-0.78 \%$; $\Delta^{199} \mathrm{Hg}(\mathrm{MIF})=-0.18 \%$ to $+0.12 \%$ [ $\mathrm{n}=33$ ]. Pleistocene-age Central Arctic Ocean sediments had average $\delta^{202} \mathrm{Hg}=-1.94 \%$ \pm $0.29 \%$ ( $1 \mathrm{sd})$ and positive $\Delta^{199} \mathrm{Hg}(+0.03 \%$ o $\pm 0.07 \%$, $1 \mathrm{sd})$, while Eocene sediments (Lomonosov Ridge IODP302) had the least negative $\delta^{202} \mathrm{Hg}$ values (average $\delta^{202} \mathrm{Hg}=-0.98 \%$ o $\pm 0.12 \%$, $1 \mathrm{sd}$ ) and $\Delta^{199} \mathrm{Hg}(\mathrm{MIF})=0.00 \% \mathrm{o} \pm 0.06 \%$ ( $\left.1 \mathrm{sd}\right)$. A sample of the Arctic Ocean PETM from Lomonosov Ridge $\left(\delta^{202} \mathrm{Hg}=-1.32 \%\right.$; $\Delta{ }^{199} \mathrm{Hg}=-0.09 \%$ ) is distinct from both Arctic Ocean Pleistocene and Eocene signatures, but similar to Holocene-age Arctic marine sediments (average $\delta^{202} \mathrm{Hg}=-1.38 \% \neq \pm 0.22 \%$; $\Delta^{199} \mathrm{Hg}=-0.05 \% \mathrm{0} \pm 0.06 \%$, $\left.1 \mathrm{sd}\right)$. Correlated $\mathrm{Hg}$ isotopic trends in MIF space $\left(\Delta^{201} \mathrm{Hg}\right.$ vs $\Delta^{199} \mathrm{Hg}$ ) for these samples indicate the presence of primarily inorganic $\mathrm{Hg}$ that underwent some degree of photochemical reduction via the magnetic isotope effect. Together with TOC data, these $\mathrm{Hg}$ isotope signatures were interpreted as a terrestrially-dominated $\mathrm{Hg}$ source input, consistent with a) independent flux estimates of $\mathrm{Hg}$ delivered by rivers to the paleo Arctic Ocean, and b) spatial patterns and down-core variability in $\mathrm{Hg}$ isotope signatures. It is concluded that the Arctic Ocean PETM $\mathrm{Hg}$ isotopic signature is most consistent with enhanced erosion and delivery of terrestriallyderived $\mathrm{Hg}$ to the paleo Arctic Ocean, rather than volcanic loading from the North Atlantic Igneous Province. More $\mathrm{Hg}$ isotope data are needed to complement ongoing $\mathrm{Hg} / \mathrm{TOC}$ concentration work at global PETM sites, and to constrain potential influences of volcanic loading on the marine environment during PETM-related hyper-thermal events.

[1] Gleason et al. (2017) Geochim. et Cosmochim. Acta 197:245-262. 